\title{
ALTRE ASIE
}

\section{Opere in lingua italiana}

AZZARONI, Giovanni, Teatro in Asia, vol.1: Malaysia, Indonesia, Filippine, Giappone, Bologna CLUEB, 1998.

AZZARONI, Giovanni, Teatro in Asia, vol.2: Myanmar, Thailandia, Laos, Kampuchea, Viêt Nam, Bologna CLUEB, 2000.

AZZARONI, Giovanni, Teatro in Asia, vol.3: Tibet, Cina, Mongolia, Corea, Bologna CLUEB, 2003.

AZZARONI, Giovanni, Teatro in Asia, vol.4: Nepal, Bhutan, India, Sri Lanka, Bologna CLUEB, 2006.

AZZARONI, Giovanni, CASARI, Matteo, Asia. Il teatro che danza, Firenze, Le Lettere, 2011.

BARBA, Eugenio, La canoa di carta, Bologna, Il Mulino, 2004 (1a ed. 1993).

OTTAVIANI, Gioia, I fondamenti del teatro in Asia. Nātyaśāstra, Yueji, i trattati di Zeami, Roma, Bulzoni, 2007.

SAVARESE, Nicola, Teatro e spettacolo fra Oriente e Occidente, Roma-Bari, Laterza, 2006.

SAVARESE, Nicola, Il teatro eurasiano, Roma-Bari, Laterza, 2002.

\section{Opere in altre lingue}

BARBA, Eugenio, MASGRAU, Lluis (ed.), The Moon Rises from the Ganges. My journey through Asian acting techniques, London, Icarus Publishing Enterprise and Routledge, 2015.

BEAMAN, Patricia, World Dance Cultures, London, Routledge, 2018.

BOUVIER, Hélène, TOFFIN, Gérard (eds.), Théâtre d'Asie à l'oeuvre. Circulation, expression, politique, Paris, EFEO, 2012. 
BRISBANE, Katherine, CHATURVEDI, Ravi, MAJUMDAR, Ramendu, CHUA SOO PONG, TANOKURA Minoru, The World Encyclopedia of Contemporary Theatre, Volume 5: Asia/Pacific, London, Routledge, 2001.

BUCK, Ralph, ROWE, Nicholas, SHAPIRO-Phim, Toni, Talking Dance: Contemporary Histories from the South China Sea, London, Bloomsbury Publishing, 2016.

BURKHALTER FLUECKIGER, Joyce, SEARS, Laurie (eds.), Boundaries of the Text. Epic Performances in South and Southeast Asia, Ann Arbor, University of Michigan Press, 1991.

FEUILLEBOIS-PIERUNEK, Eve (dir.), Théâtres d'Asie et d'Orient. Traditions, rencontres et métissages, Bruxelles, P.I.E. Peter Lang, 2012.

LIU Siyuan, Routledge Handbook of Asian Theatre, London, Routledge, 2016.

LIU Siyuan, WETMORE, Kevin J. Jr, The Methuen Drama Anthology of Modern Asian Plays, London, Bloomsbury, 2014.

MADHAVAN, Arya, Women in Asian Performance. Aesthetics and politics, London, Routledge, 2017.

MEZUR, Katherine, Wilcox, Emily (eds.), Corporeal Politics. Dancing East Asia, Ann Arbor, University of Michigan Press, 2020.

MUSEE D'ART ASIATIQUES GUIMET, Du No à Mata Hari. 2000 ans de théâtre en Asie, Paris, MNAAG, 2015.

PIMPANEAU, Sylvie, PIMPANEAU Jacques, LE BRIS, Michel (dir.), Visages des dieux, visages des hommes: masques d'Asie, Paris, Hoëbeke, 2006.

PRETKI, Tim, BREED, Ananda (eds.), The Routledge Companion to Applied Performance, Volume Two - Brazil, West Africa, South and South East Asia, United Kingdom, and the Arab World, London, Routledge, 2021.

QUILLET, Françoise, Le théâtre s'écrit aussi en Asie, Paris, L'Harmattan, 2011.

QUILLET, Françoise, Besançon, Théâtres contemporains en Asie, Presses universitaires de Franche-Comté, 2016.

ROGERS, Amanda, Performing Asia Transionalisms. Theatre, Identity and the Geographies of Performance, London, Routledge, 2015, ill.

SAKAKIBARA Kiitsu, Dances of Asia, Chandigarth, India, Abhishek Publications, 1992. SENGUPTA, A., Mapping South Asia through Contemporary Theatre. Essays on the Theatres of India, Pakistan, Bangladesh, Nepal and Sri Lanka, London, Palgrave Macmillan, 2014. 
TAN, Marcus, RAJENDRAN, Charlene, Performing Southeast Asia. Performance, Politics and the Contemporary, London, Palgrave Macmillan, 2020.

TIAN, Min, The Use of Asian Theatre for Modern Western Theatre: the Displaced Mirror, London, Palgrave, 2018.

TUAN, Iris H., Translocal Performance in Asian Theatre and Film, London, Palgrave Pivot, 2018.

TUAN, Iris H., CHANG I-chu, Transnational Performance, Identity and Mobility in Asia, London, Palgrave Pivot, 2018.

UM, Hae-kyung (ed.), Diasporas and Interculturalism in Asian Performing Arts. Translating Traditions, London, Routledge, 2005.

WEINTRAUB, Andrew N., BARENDREGT, Bart (eds), Vamping the Stage: Female Voices of Asian Modernities, Honolulu, University of Hawai'i Press, 2017.

WETMORE, Kevin J. Jr, LIU Siyuan, MEE, Erin B., Modern Asian Theatre and Performance 1900-2000, London, Bloomsbury Methuen Drama, 2014.

\section{CAMBOGIA}

BURRIDGE, Stephanie, FRUMBERG, Fred, Beyond the Apsara: Celebrating Dance in Cambodia, London, Routledge, 2010.

CHAU-PECH OLLIER, Leakthina, WINTER, Tim, Expressions of Cambodia: The Politics of Tradition, Identity and Change, London, Routledge, 2006.

CRAVATH, Paul, Earth in flower: the divine mystery of the Cambodian dance drama, Holmes Beach, FL, 2007.

DIAMOND, Catherine, Communities of imagination: contemporary Southeast Asian theatres, Honolulu, University of Hawai'i Press, 2012.

GOODLANDER, Jennifer, Puppets and cities: articulating identities in Southeast Asia, London, UK; New York, NY, Methuen Drama, 2019.

HEYWOOD, Denise, Cambodian Dance: Celebration of the Gods, Bangkok, River Books, 2009. 
KRAVEL, Pech Tum, Sbek Thom: Khmer Shadow Theater, edited by Martin Hatch, Sos Kem, Thavro Phim, Ithaca, Cornell University Southeast Asia Program and UNESCO, 1995.

MOLY SAM, Chan, Khmer Court Dance: A Comprehensive Study of Movements, Gestures, and Postures as Applied Techniques, s.1., Khmer Studies Institute, 1987.

MOROTTI, Fabio, Teatro e danza in Cambogia, Spoleto, Editoria \& spettacolo, 2010.

PHIM, Toni S., THOMPSON, Ashley, Dance in Cambodia, Oxford, Oxford University Press, 1999.

SHAPIRO, Toni, Dance and the Spirit of Cambodia, Ithaca, NY., Cornell University, 1994.

\section{COREA}

AA.VV., Drama, Dance and Music, Seoul, Jipmoondang Publishing Co., 1997.

AA.VV., Korean Dance, Theater and Cinema, edited by the Korean National Commission for UNESCO, Seoul, The Si-sa-yong-o-sa Publishers Inc., 1983.

AA.VV., Korean Intangible Cultural Properties. Folk, Dramas, Games and Rites, vol. I, Seoul, Office of Cultural Properties-Ministry of Culture and Sports, 1997.

BRANDON, James, The Cambridge Guide to Asian Theatre, Cambridge, Cambridge University Press, 2000 (1st ed. 1993).

CHO, Dong-Il, Korean Mask Dance, Seoul, Ewha Womans University Press, 2005.

CH'OE, Sang-Su, A Study Mask Play of Ha Hoe, Seoul, 1959.

CH’OE, Sang-Su, A Study of Korean Puppet Play, Seoul, Korea Books Pub. Co., 1961.

CHŎNG, In-Sŏp, Plays from Korea, Seoul, Chung-ang University, 1980.

CHONG, Pyong-Hi, Danses masquées et jeux de marionettes en Corée, Paris, Publications Orientalistes de France, 1975.

CHUN, Shin-Yong, Culture of Korea, Seoul, International Cultural Foundation, 1982.

CHUN, Shin-Yong, Folk Culture in Korea, Seoul, International Cultural Foundation, 1974.

DALlET, Charles, Folk Art and Magic Shamanism in Korea, New Jersey and Seoul, Hollym Corporation, 1986. 
EMSHEIMER, Ernst, Musik, Lied, Tanz in Korea, Bonn, Bouvier and Co. Verlag, 1968. HAN, Man-Yŏng, Kugak. Studies in Korean Traditional Music, Seoul, Tamgudang, 1990. HOWARD, Keith, Korean Musical Instruments, Seoul, Segwang Music Publishing Co., 1988.

HOWARD, Keith, Bands, Songs and Shamanistic Rituals. Folk Music in Korean Society, Seoul, Korea Branch of the Royal Asiatic Society, 1990 (1st edition 1989).

HUHM, Halla Pai, Kut. Korean Shamanistic Rituals, New York and Seoul, Hollym, 1980. JANG, Yeonok, Korean P'ansori Singing Tradition. Development, Authenticity, and Performance History, Lanham, MD, Scarecrow, 2013.

JANG, Wŏn-Jae, Irish Influences on Korean Theatre during the 1920s and the 1930s, New York, Oxford University Press USA, 2004.

JEON, Kyung-Wook, Korean Mask Dance Dramas: Their History and Structural Principles, Seoul, Youlhwadang Publishers, 2005.

KARDOSS, J., An Outline History of Korean Drama, New York, Long Island University Press, 1966.

KILLICK, Andrew, In Search of Korean Traditional Opera: Discourses of Ch'angguk, Honolulu, University of Hawai'i Press, Studies of the International Centre for Korean Studies, 2010.

KIM, Hae-Sook (ed.), Yeonhui: Korean performing arts, Seoul, National Gugak Center, 2015.

KIM, Joungwon (ed.), Korean Cultural Heritage. Volume III: Performing Arts,Seoul, Korea Foundation, 1997.

KIM, Pang-Ok, Contemporary Korean theater: beyond tradition and modernization, Seoul, Hollym International Corp, 2014.

KIM, Suk-Young, Illusive Utopia. Theater, Film, and Everyday Performance in North Korea, Ann Arbor, University of Michigan Press, 2010.

KIM, Woo-Ok, P'ansori. An Indigenous Theatre of Korea, Ph. D. Thesis, New York University, 1980.

KIM, Wootaek, The Traditional Korean Theatre and Its Original Stage, Seoul, Kaemun Sa., 1978.

KOO, Sunhee, Sound of the Border: Music and Identity of Korean Minority Nationality in China, Honolulu, University of Hawai'i Press, 2021.

Korean ITI, The Korean Theatre. Past and Present, Seoul, 1974. 
Korean National Commission for UNESCO (ed.), Wedding Day and Other Korean Plays,, Seoul, Si-sa-yong-o-sa Publishers, 1983.

LEE, Duhyun, Masks of Korea, Seoul, Ministry of Culture and Information, 1981.

LEE, Eun-Joo, KIM, Yong-Shin, Salpuri-chum, a korean dance for expelling evil spirits: a psychoanalytic interpretation of its artistic characteristics, Lanham, MD, Hamilton Books, 2017.

LEE, Hyunjung, Performing the Nation in Global Korea. Transnational Theatre, Basingstoke, Palgrave Macmillan, 2015.

LEE, Jaram, Le Dit de Sichuan, p'ansori moderne, traduit et présenté par Han Yumi e Hervé Péjaudier, Paris, Imago, 2010.

MALIANGKAY, Roald, Broken Voices: Postcolonial Entanglements and the Preservation of Korea's Central Folksong Traditions, Honolulu, University of Hawai'i Press, 2017.

NICHOLS, Richard (ed.), Modern Korean Drama: An Anthology, New York, Columbia University Press, 2011 (reprint edition).

OH, Kon Cho, Traditional Korean Theatre, Berkeley, Cal., Asian Humanities Press, 1988.

OH, Kon Cho, Korean Puppet Theatre - Khoktu Katsi, East Lansing, 1979.

OH, T'ae-Sok, KIM, Ah-Jeong, The Metacultural Theater of Oh T'ae-sok: Five Plays from the Korean Avant-Gard, Honolulu, University of Hawai'i Press, 1991.

PAK, Cho-Yôl, Théâtres coréens: sept pièces contemporaines. Antologie, Paris, Editions l'Harmattan, 1998.

PARK, Bong-Shik (et al.) Traditional Performing Arts of Korea, Seoul, Korean National Commission for UNESCO, 1974.

PARK, Chan E., Voices from the straw mat: toward an ethnography of Korean story singing, Honolulu, University of Hawai'i Press, 2003.

PAVIS, Patrice, Performing Korea, London, Palgrave Macmillan, 2018.

PRATT, Keith L., Korean Music. Its History and Its Performance, London-Seoul, Farber and Jung Eum Sa, 1987.

RAPIN, Cathy, IM, Hye-gyong (eds.), Théâtre coréen d'hier et d'aujourd'hui, Paris, Éd. de l'Armandier, 2006.

ROCKWELL, Coralie, Kagok. A Traditional Korean Vocal Form, Providence, Brown University, 1972.

SO, Chŏng-Nok, Korean dance through the ages, Seoul, Minsokwon, 2019. 
SON, Elizabeth W., Embodied Reckonings. "Comfort Women," Performance, and Transpacific Redress, Ann Arbor, University of Michigan Press, 2018.

SONG, Bang-Song, Korean Music. Historical and Other Aspects, Seoul, Jimoondang Publishing Company, 2000.

SONG, Bang-Song, A Short History of Korean Traditional Music, Seoul, Jimoondang Publishing Company, 1997.

UM, Haekyung, Korean Musical Drama: P'ansori and the Making of Tradition in Modernity, London, Ashgate Publishing, Ltd., 2014.

VAN ZILE, Judy, Perspectives on Korean dance, Middletown, Connecticut, Wesleyan University Press, 2001.

WALRAVEN, Boudewijin, Songs of the Shaman: The Ritual Chants of the Korean Mudang. London and New York, Kegan Paul International, 1994.

WALRAVEN, Boudewijin, Muga. The Songs of Korean Shamanism, Dordrecht, ICG, 1985.

YI, Hye-Gu Korean court dance as seen in historical documents, Seoul, Korea Foundation, 2010.

YI, Hye-Gu, Essays on Korean Traditional Music, Seoul, Korea Branch of Royal Asiatic Society, 1981.

YI, Hye-Gu, Korean Music and Dance, Seoul, Korea Branch of Royal Asiatic Society, 1977.

YI, Mi-wŏn, Contemporary Korean Theatre: Playwrights, Directors, Stage-designers, Seoul, Theatre and Man, 2000.

YI, Pyong-Ok, CHO, Yoon-Jung, Korean Folk Dance, Seoul, Korea Foundation, 2008.

YI, Po-hyǒng, P’ansori Survey of Korean Arts. Traditional Music, Seoul, National Academy of Arts, 1974.

YI, Po-hyǒng (o LEE, Bo-hyǒng), Shamanistic Music, Seoul, National Academy of Arts, 1974.

YOO, Jeungsook, A Korean Approach to Actor Training, London, Routledge, 2018.

YU, Chai-Shin, GUISSO, Richard W. I. (eds.), Shamanism: The Spirit World of Korea, Berkeley, Asian Humanities Press, 1988.

YU, Č’ 'i-ČIi, Č’ $̈$ Ă, Man-Sik, Korean Drama under Japanese Occupation, Paramus (N.J.), Homa \& Sekey Books, 2004. 


\section{FILIPPINE}

CASTRO, Christi-Anne, Musical Renderings of the Philippine Nation, Oxford University Press, 2011.

CHUA, Jonathan, CRUZ-LUCERO, Rosario (eds.), A reader in Philippine theater : history and criticism, Diliman, Quezon City, University of the Philippines Press, 2014. LACONICO-BUENAVENTURA, Cristina, The theater in Manila, 1846-1946, Quezon City, Philippines, C \& E Pub., 2010.

PETERSON, William, Places for happiness: community, self, and performance in the Philippines, Honolulu, University of Hawai'i Press, 2016.

PINEDA TIATCO, Sir Anril, Cosmopolitanism, theatre, and the Philippines: performing community in a world of strangers, Quezon City, University of the Philippines Press, 2018.

PINEDA TIATCO, Sir Anril, Buhol Buhol/Entanglement: Contemporary Theatre in Metropolitan Manila, Bern, Peter Lang Gmbh, Internationaler Verlag Der Wissenschaften, 2017.

PINEDA TIATCO, Sir Anril, Performing Catholicism: faith and theater in a Philippine province, Diliman, Quezon City, University of the Philippines Press, 2016.

PINEDA TIATCO, Sir Anril, Entablado: theaters and performances in the Philippines, Diliman, Quezon City, University of the Philippines Press, 2015.

VILLARUZ, Basilio Esteban S., Walking through Philippine theater, Manila, University of Santo Tomas Pub. House, 2012.

YAMOMO, MeLé, Theatre and Music in Manila and the Asia Pacific, 1869-1946. Sounding Modernities, London, Palgrave Macmillan, 2018. 


\section{INDONESIA}

\section{Opere in lingua italiana}

AZZARONI, Giovanni, Società e teatro a Bali, Bologna, CLUEB, 1994.

DI BERNARDI, Vito, Introduzione allo studio del teatro indonesiano: Giava e Bali, Firenze, La casa Usher, 1995.

DI BERNARDI, Vito, LUIJDJENS, Adriano H., Giava-Bali: rito e spettacolo, Biblioteca di cultura, Roma, Bulzoni, 1985.

INVERNIZZI, Luca, CASSIO, Alberto, Wayang Purwa: il teatro d'ombre nella cultura giavanese. Museo di antropologia ed etnografia, Torino, Libreria editrice universitaria Levrotto \& Bella, 1977.

MAROTTI, Ferruccio, Trance e dramma a Bali: per un teatro della crudeltà, Torino, Cooperativa editoriale Studio Forma, 1976.

SAVARESE, Nicola, Paris/Artaud/Bali. Antonin Artaud vede il teatro balinese all'Esposizione Coloniale di Parigi del 1931, Imola, CUE Press, 2021.

\section{Opere in altre lingue}

AA. VV., The Lontar Anthology of Indonesian Drama, vol. 1: Plays for Popular Stage (edited by Matthew Isaac Cohen, John H. McGlynn), Jakarta, Lontar Foundation, 2010. AA. VV., The Lontar Anthology of Indonesian Drama, vol. 2: Building a National Theater (edited by Michael Bodden, John H. McGlynn), Jakarta, Lontar Foundation, 2010. AA. VV., The Lontar Anthology of Indonesian Drama, vol. 3: New Directions (edited by Cobina Gillit, John H. McGlynn), Jakarta, Lontar Foundation, 2010.

AA. VV., Traditional Theatre in Southeast Asia, Singapore, UniPress for SPAFA and Centre for the Arts, National University of Singapore, 1995.

ANDRIEU, Sarah Anaïs, Corps de bois, souffle humain: le théâtre de marionnettes Wayang golek de Java Ouest, Rennes, Presses Universitaires de Rennes, 2014.

ARPS, Bernard, Tall Tree, Nest of the Wind: The Javanese Shadow-play Dewa Ruci Performed by Ki Anom Soeroto: A Study in Performance Philology, Singapore, NUS Press, 2016. 
ARPS, Bernard (ed.), Performance in Java and Bali: studies of narrative, theatre, music, and dance, London, School of Oriental and African studies, University of London, 1993. ASSER, Saskia, THEUNS-DE BOER, Gerda, Isidore van Kinsbergen, 1821-1905: Photo Pioneer and Theatre Maker in the Dutch East Indies, s.l., Kitlv Press, 2005.

BASSET, Catherine, PICARD, Michel, Bali l'ordre cosmique et la quotidienneté, Paris, Autrement/série monde hors série n66, 1993.

BASSET, Catherine, Musiques de Bali à Java l'ordre et la fête, Paris, Cité de la Musique/Actes Sud collection "Musique du Monde", 1995.

BECKER, Judith (ed.), Karawitan. Source Readings in Javanese Gamelan and Vocal Music, Volume 1, Ann Arbor, University of Michigan Press, 1984.

BECKER, Judith (ed.), Karawitan. Source Readings in Javanese Gamelan and Vocal Music, Volume 2, Ann Arbor, University of Michigan Press, 1987.

BECKER, Judith (ed.), Karawitan. Source Readings in Javanese Gamelan and Vocal Music, Volume 3, Ann Arbor, University of Michigan Press, 1988.

BODDEN, Michael H., Resistance on the National Stage: Theater and Politics in Late New Order Indonesia, Athens, OH, Ohio University Press, Ohio RIS Southeast Asia Series, 2010.

BRANDON, James, Theatre in Southeast Asia, Cambridge, MA, Harvard University Press, 1967.

BRANDON, James, The Cambridge Guide to Asian Theatre, Cambridge, Cambridge University Press, 2000 (1st ed. 1993).

BRANDON, James (ed.), LONG, Roger A. (ph.), On Thrones of Gold: Three Javanese Shadow Plays, Honolulu, University of Hawai'i Press, 1993.

COAST, John, Dancing out of Bali, North Clarendon, VT, Tuttle Publishing, 2012.

COHEN, Matthew Isaac, The Komedie Stamboel. Popular Theater in Colonial Indonesia, 1891-1903, Athens, OH, Ohio University Press, 2006.

COHEN, Matthew Isaac, Performing Otherness: Java and Bali on International Stage, 1905-1952 (Studies in International Performance), London, Palgrave Macmillan, 2010. CHONG, Terence, The Theatre and the State in Singapore. Orthodoxy and Resistance, London, Routledge, 2007.

DE ZOETE, Beryl, SPIES, Walter, Dance and drama in Bali, Kuala Lumpur; London; New York, Oxford University Press; Jakarta, Bhratara, 1973. 
DIBIA, I Wayan, BALLINGER, Rucina, (ANELLO, Barbara, ill.), Balinese Dance, Drama and Music: A Beginner's Guide to the Performing Arts of Bali, North Clarendon, VT, Tuttle Publishing, 2021.

DIBIA, I Wayan, BALLINGER, Rucina, (ANELLO, Barbara, ill.), Balinese Dance, Drama and Music: A Guide to the Performing Arts of Bali, North Clarendon, VT, Tuttle Publishing, 2011.

EISEMAN, Fred, Bali: Sekala \& Niskala, North Clarendon, VT, Tuttle Publishing, 2009. EMIGH, John, Masked performance: the play of self and other in ritual and theatre, Philadelphia, University of Pennsylvania Press, 1996.

FASSOLA, Jacques, Bali, jardin des immortels, Paris, Editions du Chêne, 1983.

FRASER, Jennifer A, Gongs and Popsongs. Sounding Minangkabau in Indonesia, Athens, OH, Ohio University Press, 2015.

GEERTZ, Clifford, Negara: The Theatre State in Nineteenth-Century Bali, Princeton, Princeton University Press, 1980.

GINN, Victoria, Tihei Mauriora l'echo de la terre, danses, mythes et rites du sud asiatique au pacifique sud, Paris, Arthaud, 1990.

GOODLANDER, Jennifer, Women in the Shadows. Gender, Puppets, and the Power of Tradition in Bali, Athens, OH, Ohio University Press, 2016.

GRÜND, Françoise, Danses de la terre, La Martinière, 2001.

HARNISH, David D., Change and Identity in the Music Cultures of Lombok, Indonesia, Leiden, Brill, 2021.

HARNISH, David D., RASMUSSEN, Anne (eds.), Divine Inspirations: Music and Islam in Indonesia, New York, Oxford University Press USA, 2011.

HARTLEY, Barbara with HOUGH, Brett (eds.), Performing contemporary Indonesia: celebrating identity, constructing community, Leiden; Boston, Brill, 2015.

HARTLEY, Barbara, Ketoprak theatre and the wayang tradition, Clayton, Vic., Australia, Centre of Southeast Asian Studies, Monash University, 1979.

HARTLEY, Barbara, Javanese Performances on an Indonesian Stage: Celebrating Culture, Embracing Change, Honolulu, University of Hawai'i Press, ASAA Southeast Asia Publications, 2008.

HOBART, Angela, Dancing Shadows of Bali: Theatre and Myth, London, New York, KPI, 1987.

KARTOMI, Margaret (ed.), Performing the arts of Indonesia: Malay identity and politics in the music, dance and theatre of the Riau Islands, Copenhagen, NIAS Press, 2019. 
KATZ-HARRIS, Felicia, Inside the Puppet Box: A Performance Collection of Wayang Kulit at the Museum of International Folk Art, Santa Fe, Museum of International Folk Art, 2010.

IRVINE, David, Leather Gods \& Wooden Heroes. Java and Classical Wayang, Singapore, Times Editions, 2006.

LYSLOFF, René, Srikandhi Dances Lènggèr: A Performance of Music and Shadow Theater in Central Java, Leiden, Brill, 2012.

MEYER, Charles, BRUNET, Jacques, TOURLET-DIVEDI, Cristiane, SHASTRI Pandit Vishwanath, AUBRY, Chantal, Ramayana, de l'epopée au spectacle, La Croixl'Evenement/Festival d'Avignon, 1990.

MIETTINEN, Jukka O., Classical Dance and Theater in South-East Asia, New York, Oxford University Press, 1993.

MRÁZEK, Jan, Puppet Theater in Contemporary Indonesia: New Approaches to Performing Events, Ann Arbor, University of Michigan Press, 2002.

NOSZLOPY, Laura, COHEN, Matthew Isaac (eds.), Contemporary Southeast Asian Performance: Transnational Perspectives, Cambridge, Cambridge Scholars Publishing, 2010.

PAUKA, Kirstin, Theater \& Martial Arts in West Sumatra: Randai \& Silek of Minangkabau, Athens, OH, Ohio University Press, Ohio RIS Southeast Asia Series, 1998. PEACOCK, James, Rites of Modernization: Symbolic and Social Aspects of Indonesian Proletarian Drama, Chicago, University of Chicago Press, 1987.

PETERSON, William, Theater and the Politics of Culture in Contemporary Singapore, Middletown, CT., Wesleyan University Press, 2001.

PRATT WALTON, Susan, Mode in Javanese Music, Athens, OH, Ohio University Press, 1987.

PURWOSEPUTRO, Ardian, Wayang potehi of Java, Jakarta, Afterhours Books, 2014. RAFFERTY, Ellen, Putu Wijaya in Performance: A Script and Study of Indonesian Theatre, Madison Wi., Center for Southeast Asian Studies, University of Wisconsin, 2004. REICHLE, Natasha, Bali: Art, Ritual, Performance, San Francisco CA., Asia Art Museum, 2011.

ROBSON, Cheryl (ed.), New Indonesian Plays, London, Aurora Metro Books, 2019.

RUBIN, Leon, NYOMAN SEDANA, I., Performance in Bali, London, Routledge, 2009. SEARS, Laurie Jo, Shadows of Empire: Colonial Discourse and Javanese Tales, Durham and London, Duke University Press, 1996. 
SLATTUM, Judy, SCHRAUB, Paul, Masks of Bali, San Francisco, CA., Chronicle Books, 1992.

SLATTUM, Judy, SCHRAUB, Paul, Balinese Masks: Spirits of an Ancient Drama, Tōkyō, North Clarendon, VT, Tuttle Publishing, 2012.

SPIES, Walter, de ZOETE, Beryl, Dance and Drama in Bali, Hong Kong, Periplus, 2002.

STILLER, Henry, Javaphilia: American Love Affairs with Javanese Music and Dance, Honolulu, University of Hawai'i Press, 2015.

STENBERG, Josh, Minority stages: Sino-Indonesian Performance and Public Display, Honolulu, University of Hawai'i Press, 2019.

SUDARSONO, Living traditional theaters in Indonesia: nine selected papers, Yogyakarta, Akademi Seni Tari Indonesia, 1974.

TENZER, Michael, Balinese Gamelan Music, North Clarendon, VT, Tuttle Publishing, 2011.

TENZER, Michael, Gamelan Gong Kebyar: The Art of Twentieth-Century Balinese Music, Chicago and London, University of Chicago Press, 2000.

THEUNS-DE BOER, Gerda, ASSER, Saskia, WACHLIN, Steven, Isidore van Kinsbergen, 1821-1905: Photo Pioneer and Theatre Maker in the Dutch East Indies, Honolulu, University of Hawai'i Press, 2010.

WEINTRAUB, Andrew N., Power Plays: Wayang Golek Puppet Theater of West Java, Athens, OH, Ohio University Press, Ohio RIS Southeast Asia Series, 2004.

WINET, Evan Darwin, Indonesia Postcolonial Theatre: Spectral Genealogies and Absent Faces (Studies in International Performance), London, Palgrave Macmillan, 2010. Van ZANTEN, Wim, Music of the Baduy People of Western Java, Leiden, Brill, 2021. 


\section{IRAN}

BEEMAN, William O., Iranian performance traditions, Costa Mesa, CA., Mazda Publishers, 2011.

FLOOR, Willem M., The History of The Persian Theatre, Washington, Mage, 2005.

MELLOR, Aubrey, ROBSON, Cheryl (eds.), New Iranian Plays, London, Aurora Metro Publications Limited, 2021.

GHANOONPARVAR Mohammad R., GREEN, John (eds.), Iranian Drama: An Anthology, Costa Mesa, CA., Mazda Publishers, 1989.

GHOLAMI, Saloumeh (ed.), Dance in Iran: past and present, Wiesbaden, Reichert, 2016. ISALOO, Amin Sharifi, Power, legitimacy and the public sphere: the Iranian Ta'ziyeh Theatre ritual, London; New York, Routledge, 2017.

KHAJEHI, Yassaman, La marionnette iranienne ou Les pouvoirs d'un objet hybride, Paris, Classiques Garnier, 2020.

MALEKPOUR, Jamshid (Ǧamšīd), The Islamic Drama, London; Portland (Or.), Frank Cass, 2004.

MEFTAHI, Ida, Gender and dance in modern Iran: biopolitics on stage, London, Routledge, 2016.

NAJAFI ARDABILI, Masoud, Grotowski in Iran, Berlin; New York, Peter Lang, 2019. NAJIMI, Fahimeh, Le théâtre, l'Iran et l'Occident, Paris, l'Harmattan, 2018.

NeMATOLlahi MAHANI, Mahnia A., The holy drama: Persian passion play in modern Iran, Leiden, Leiden University Press, 2013.

RAHIMI, Babak, Theater state and the formation of early modern public sphere in Iran: studies on Safavid Muharram rituals, 1590-1641 CE, Leiden, Brill, 2012.

RAINFAR, Iraj, L'évolution et les fonctions scéniques du Taazié, Mémoire de maîtrise: Théâtre, Paris 8, 1979.

REZVANI, Medjid-Kahn, Le Théâtre et la danse en Iran, Plan-de-la-Tour, Éditions d'Aujourd'hui, 1981.

ȘAYYĀD, Parvīz, Parviz Sayyad's Theater of diaspora: two plays, The ass and The Rex Cinema trial; edited by Hamid Dabashi with a foreword by Peter Chelkowski, Costa Mesa, CA., Mazda Publishers, 1993.

SHAHRIARI, Khosrow, A different approach to a unique theatre: taziyeh in Iran, Kista, Sweden, Kitab-i Arzan, 2008. 
VARZI, Roxanne, Last scene underground: an ethnographic novel of Iran, Stanford, CA., Stanford University Press, 2016.

\section{MALESIA}

BRANDON, James, The Cambridge Guide to Asian Theatre, Cambridge, Cambridge University Press, 2000 (1st ed. 1993).

ABDULLAH, Nur Afifah Vanitha, Persembahan bangsawan di Sarawak, Kota Samarahan, Universiti Malaysia Sarawak, 2011.

ABDULlAH, Nur Afifah Vanitha, Nora and Hedda in Malaysian theatre, Kota Samarahan, Sarawak, Malaysia, Universiti Malaysia Sarawak, 2011.

CHONG, Terence, The Theatre and the State in Singapore, London, Routledge, 2013.

CUISINIER, Jeanne, Le Théâtre d'ombres à Kelantan, Paris, Gallimard, 1957.

GHULAM-SARWAR, Yousof, Mak Yong through the Ages: Kelentan's Traditional Dance Theatre, Kuala Lumpur, University of Malaya Press, 2018.

GHULAM-SARWAR, Yousof, Encyclopedia of Malaysia, vol. 8: Performing Arts, Singapore, Didier Millet, Csi, 2001.

GHULAM-SARWAR, Yousof, Mak Yong: Wolrd Heritage Theatre, Penang, Areca Books, 2019.

HATTA Azad Khan, Four musical theatres, Kuala Lumpur, Institut Terjemahan \& Buku Malaysia, 2014.

JENNING, Sue, Theatre, ritual, and transformation: the Senoi Temiars, London, Routledge, 2018.

LO, Jacqueline, Staging Nation: English Language Theatre in Malaysia and Singapore, Hong Kong, Hong Kong University Press, 2004.

MATUSKY, Patricia, The music of Malaysia: the classical, folk and syncretic traditions, Abingdon, Oxon; New York, NY, Routledge, 2017.

MILLIE, Julian, Bidasari: Jewel of Malay Muslim Culture, Honolulu, University of Hawai'i Press, Bibliotheca Indonesica \#31, 2010.

MOHD, Anis Md Nor, BURRIDGE, Stephanie (eds.), Sharing Identities. Celebrating Dance in Malaysia, London, Routledge, 2011. 
OSNES, Beth, The Shadow Puppet Theatre of Malaysia: A Study of Wayang Kulit with Performance Script and Puppet Designs, Jefferson, N.C., McFarland, 2010.

RAJENDRAN, Charlene, TAKIGUCHI Ken, NGE, Carmen (eds.), Excavations, interrogations, Krishen Jit \& contemporary Malaysian theatre, Singapore, Epigram Books; Kuala Lumpur, Malaysia, Five Arts Centre Sdn. Bhd., 2018.

SARKISSIAN, Margaret, D'Albuquerque's Children: Performing Tradition in Malaysia's Portuguese Settlement, Chicago, University of Chicago Press, 2000.

SMITH, Philip, Shakespeare in Singapore. Performance, Education and Culture, London, Routledge, 2020.

SWEENEY, Amin, Malay Shadow Puppets: the Wayang Siam of Kelantan, London, The Trustees of the British Museum, 1972.

TAN, SOOI BENG, Ko-Tai: A New Form of Chinese Urban Street Theatre in Malaysia, Singapore, ISEAS, 1984.

ZAHARI, Rahimidin, UMAR RS, Sutung, et al., Makyung, the mystical heritage of Malaysia, Kuala Lumpur, Malaysian National Institute of Translation, 2011.

\section{MONGOLIA}

GUEVARA, Ruben, Confessions of a radical Chicano doo-wop singer, Oakland, California, University of California Press, 2018.

LEGRAIN, Laurent, Chanter, s'attacher et transmettre chez les Darhad de Mongolie, Paris, Centre d'études mongoles \& sibériennes, École pratique des hautes études, 2014. MARSH, Peter K., The horse-head fiddle and the cosmopolitan reimagination of tradition in Mongolia, New York, Routledge, 2009.

PEGG, Carole, Mongolian Music, Dance, \& Oral Narrative: Performing Diverse Identities, Seattle \& London, University of Washington Press, 2001. 


\section{MYANMAR}

BRUNS, Axel, Burmese puppetry, Bangkok, Thailand, White Lotus Press, 2006.

ERLICH, Daniel J., Backstage Mandalay: the netherworld of the Burmese performing arts, Bangkok, River Books, 2012.

MA MA NUIN', The wiles of the dancing strings, Ma Ma Naing (Mandalay Marionettes), Yangon, Pannmyo Tayar Publishing, 2013.

THANEGI, Ma, Myanmar marionettes, Yangon, Asia Publishing House, 2008.

THANEGI, Ma, Illusions of Life: Burmese Marionettes, Bangkok, White Orchid Books, 1994.

YE DWAY, Marionettes of Myanmar, Yangon, Sarpay Beikman, 2013.

YE DWAY, Myanmar dance and drama, Yangon, Today Publishing House, 2014.

\section{NEPAL e paesi himalayani}

BUFFETRILLE, Katia, Revisiting Rituals in a Changing Tibetan World, Leiden, Brill, 2012.

DAVIS, Carol C., Theatre of Nepal and the People Who Make it, Cambridge, Cambridge University Press, 2019.

KOHN, Richard J., Lord of the Dance: The Mani Rimdu Festival in Tibet and Nepal, Albany, NY, SUNY Press, 2001.

MARTIN, Matthew, Tantra, Ritual Performance, and Politics in Nepal and Kerala. Embodying the Goddess-clan, Leyden, Brill, 2020.

MOTTIN, Monica, Rehearsing for life: theatre for social change in Nepal, Cambridge, Cambridge University Press, 2018.

PANNIER, François, WANG-TOUTAIN, Françoise, POMMARET, Françoise, DATABUIT, Eudald, La danse des morts. Citipati de l'Himalaya, Danses macabres et Vanités de l'Occident, Paris, éditions Findakly, 2004.

TSE BARTHOLOMEW, Terese, JOHNSTON, John (dir.), Au pays du dragon: arts sacrés du Bhoutan, Paris, RMN: Musée Guimet, 2009. 
UPRETY, Sanjeev, PIYA, Robin (eds.), IMAP reader: a collection of essays on art and theatre in Kathmandu, Kathmandu, Himal Books for the Interactive Mapping \& Archive Project, Social Science Baha, 2011.

\section{TAILANDIA}

HEMMET, Christine, Nang Talung: The Shadow Theatre of South Thailand, Amsterdam, KIT, Tropenmuseum, 1996.

RUTNIN, Mattani Mojdara, Dance, Drama, and Theatre in Thailand: The Process of Development and Modernization, Chiang Mai (Thailand), Silkworm Books, 1996.

SHAHRIARI, Andrew C., Khon Muang Music and Dance Traditions of North Thailand, Bangkok, White Lotus Press, 2006.

\section{TIBET}

\section{Opere in lingua italiana}

ATTISANI, Antonio, Il teatro del Tibet, Roma, Millelire Stampa Alternativa, 1993.

ATTISANI, Antonio (cur.), Fiabe teatrali del Tibet, Firenze, Titivillus, 1996.

ATTISANI, Antonio, A ce lha mo. Studio sulle forme della teatralità tibetana, Firenze, Olschki, 2001.

ATTISANI, Antonio, Uno strano teatro, Torino, Legenda, 2001.

CONSONNI, Alessandra (ed.), Cham yig: il libro tibetano delle danze, Bologna, CLUEB, 2008.

DOWMAN, Keith, La danzatrice del cielo. La vita segreta ed i canti di Yeshe Tsogyel, Roma, Astrolabio-Ubaldini, 1985.

HELFFER, Mireille (cur.), Musiche dal tetto del mondo, Torino, Testo \& Immagine, 2000. VERNI, Piero, SEVEGNANI, Vicky, Tibet. Danze rituali dei Lama, Firenze, Nardini, 1980. 


\section{Opere in altre lingue}

AA. VV., A Collection of Eight Main Tibetan Opera, Lhasa, Tibetan People's Publishing House, 1989.

AA. VV., Buddhist Ritual Dance, Kathmandu, Kala Mandapa - Institute of Classical Nepalese Performing Arts, 1986.

BACOT, Jacques, Trois mystères tibétains: Tchrimekundan-Djroazanmo-Nansal.

Répresentations théâtrales dans les monastères du Tibet, Paris, L’Asiathèque, 1987.

BACOT, Jacques, Three Tibetan mysteries. Tchrimekundan, Nasal, Djroazanmo, as performed in the Tibetan monasteries, translated from the French version of J. Bacot (with an introduction, notes, and index) by H. I. Woolf. Illustrated from native designs by V. Goloubew, Taipei, SMC Publishing, 2008 (1st edition 1923, London, Routledge and Sons).

BARTHOLOMEW, Terese, JOHNSTON, John (eds.), The Dragon's Gift: The Sacred Art of Bhutan, Hawaii, Honolulu, HI, Honolulu Academy of Arts/Chicago, Serindia Publications, 2009.

BERG, Eberhard, The Sherpa Dumiji masked dance festival. An ethnographic description of the "great liturgical performance" as celebrated annually according to the tradition of the Lamaserwa clan of the village temple of Gonpa Zhung, Solu, Lumbini International Research Institute, 2008.

CADONNA, Alfredo (ed.), India, China, Tibet. Genesis and Aspects of Traditional Narrative, Firenze, Olschki, 1999.

CADONNA, Alfredo, BIANCHI, Ester (eds.), Facets of Tibetan Religious Tradition and Contacts with Neighbouring Cultural Areas, Firenze, Olschki/Fondazione Giorgio Cini, Istituto Venezia e l'Oriente, 2001.

DOWMAN, Keith, Sky Dancer. The Life and Songs of the Lady Yeshe Tsogye, London, Routledge \& Kegan, 1984.

DUNCAN, Herbert Marion, More Harvest Festival Dramas in Tibet, London, Mitre Press, 1968.

EKVALL, Robert Brainerd, Thubten Jigme Norbu (tr.),The Younger Brother Don Yod, being the Secret Biography from the Words of the Glorious Lama, the Holy Reverend Blo bzang ye shes: a Tibetan Play, Bloomington, Indiana University Press, 1969. 
ELLINGSON, Terry Jay, The Mandala of Sound: Concepts and Sound Structures in Tibetan Ritual Music, Ph. Dl. Thesis, Madison, University of Wisconsin, 1979.

ELLINGSON, Terry Jay, SNYDER, Jeanette (eds.), Music and Theatre in Tibetan Society, Mexico City, Atti del Fonapas, 1981.

EPSTEIN, Lawrence, SHERBURNE, Richard (eds.), Reflections on Tibetan Culture. Essays in Memory of Turrell V. Wylie, Lewinston, The Mellen Press, 1990.

FANTIN, Mario, Mani Rimdu. The Buddhist Dance Drama of Tengpoche, New Delhi, The English Book Store, 1976.

HELFFER, Mireille, Les chants dans l'épopée tibétaine de Ge-sar d'après le livre de la course de cheval, Genève-Paris, Librairie Droz, 1977.

HELFFER, Mireille, Mchod-rol. Les instruments de la musique tibétaine, Paris, Editions de la Maison des Sciences de l'Homme, 1994.

HENRION-DOURCY, Isabelle, Le théâtre ache lhamo: jeux et enjeux d'une tradition tibétaine, Leuven, Peeters, 2017.

JAMYANG, Wangmo, Dancing in the Clouds: The Mani Rimdu, Dumche and Tsogchen Festivals of the Khumbu Sherpas, Kathmandu, Vajra Publications, 2008.

JERSTAD, Luther G., Mani-Rimdu: Sherpa Dance Drama, Seattle, University of Washington Press, 1969.

JINPA, Thupten, Tales from the Tibetan operas, translated by Gavin Kilty, Somerville, Mass., Wisdom Publications, 2019.

JOSAYMA BRIDGMAN, Cynthia, TSONAWA Norbu Losang, Tibetan Folk Opera, Drowa Sangmo (The Life Story of Drowa Sangmo) Dharamsala, LTWA-Library of Tibetan Works and Archives, 1990 (reprint Delhi, Paljor Publications, 2001).

JOSAYMA BRIDGMAN, Cynthia (tr.), Gyalsa Besa. Tibetan Folk Opera Story. The Story of the Marriage of King Songtsen Gampo of Tibet to the Princess of China and Nepal, Dharamsala, LTWA-Library of Tibetan Works and Archives, 1991.

KAUFMANN, Walther, Tibetan Buddhist Chant, Bloomington, Indiana University Press, 1982.

KOHN, Richard J., Lord of the Dance: The Mani Rimdu Festival in Tibet and Nepal, New York, SUNY, 2001.

MAGNIEN, Marius, Symphonies tibétaines, Genève, Librairie Rousseau, 1963.

MILLER, B.D., The Black Hat Dance, New York, Dodd, Mead \& Co., 1987. 
MÜLlER, Claudius C., RAUNING, Walter (eds.), Der Weg zum Dach der Welt (Anlässlich der grossen Tibet- Austellung im staatlichen Museum für Völkerkunde), Frankfurt am Main, Pinguin Verlag, 1982.

NEBESKY-WOJKOWITZ, René (de), Tibetan Religious Dance. Tibetan Text and Annotated Translation of the 'chams yig, New Delhi, Pilgrim Books/Paljor Publications, 1997.

NORBU, Chopel, Folk Culture of Tibet, Dharamsala, LTWA, 1983.

NORBU, Jamyang, Zlo-Gar. Performing Traditions of Tibet, Dharamsala, Library of Tibetan Works and Archives, 1986.

NORBU, Tsering, Ache Lhamo is My Life, Torino, Legenda, 1999.

PEARLMAN, Ellen, Tibetan Sacred Dance: A Journey into Religious and Folk Traditions, Rochester, VT, Inner Traditions, 2003.

RICARD, Matthieu, Moines danceurs au Tibet, Paris, Albin Michel, 1999.

RICARD, Matthieu, Monk Dancers of Tibet, Boston, Shambhala Publications, 2003.

RIGZIN, Tsepak, Festivals of Tibet, Dharamsala, LTWA-Library of Tibetan Works and Archives, 1993.

ROSS, Joanna, Lhamo: Opera from the Roof of the World, New Delhi, Paljor Publications, 1995.

SAMTEN G. KARMAY, Three Sacred Bon Dances, Solan, Yungdrung Bon Monastic Centre, 1983.

UMADEVI, The Dance of Tibet, New Delhi, Nalanda Press, 1966.

VANDOR, Ivan, La musique du bouddhisme tibétain, Paris, Editions Buchet-Chastel, 1976.

YAO, Wang, Tales from Tibetan Opera, Beijing, New World Press, 1986. 


\section{VIETNAM}

DÁVILA, Celina, COSSU, Giorgio, Sur les traces du peuple de l'eau: le théâtre de marionnettes au Vietnam, Nîmes, Grandir; Torino, Istituto per i beni marionettistici e il teatro popolare, 2013.

DINH QUANG [et al.], Le théâtre vietnamien, Hà nội, Editions Thế Giớ, 1998.

FLICKER, Corinne, PHUONG NGOC, Nguyen (dir.), Théâtres français et vietnamien: un siècle d'échanges (1900-2008): réception, adaptation, métissage, Aix-en-Provence, Presses universitaires de Provence, 2014.

GAUDRY, Alice, Le théâtre de marionnettes sur eau du Việt Nam: jouer avec le fluide, Paris, l'Harmattan, 2014.

NGUYỄ̃, Huy Hồng, Les marionnettes sur eau traditionnelles du Vietnam, Hà nội, Thế Giớ, 2006.

NORTON, Barley, Songs for the Spirits: Music and Mediums in Modern Vietnam, University of Illinois Press, 2010.

TRÂN Văn Khê, Marionnettes sur eau du Vietnam, Paris, Maison des cultures du monde, 2017. 
Bibliografia a cura di Rossella Marangoni.

Con il contributo della Fondazione Ada Ceschin Pilone e di teatrocinese.it

Versione accresciuta e aggiornata al 2021.

La prima versione era stata pubblicata in AsiaTeatro, Anno I (2011) alle seguenti pagine: http://www.asiateatro.it/giappone/bibliografia/ http://www.asiateatro.it/giappone/bibliografia/bibliografia-noh/ http://www.asiateatro.it/giappone/bibliografia/bibliografia-kabuki/ http://www.asiateatro.it/giappone/bibliografia/bibliografia-bunraku/ http://www.asiateatro.it/giappone/bibliografia/atti-dei-convegni-aistugia-saggi-sul-teatrogiapponese/ http://www.asiateatro.it/india/bibliografia/ http://www.asiateatro.it/cina/bibliografia/ http://www.asiateatro.it/asie/bibliografie/ http://www.asiateatro.it/asie/bibliografie/corea/ http://www.asiateatro.it/asie/bibliografie/bibliografia-indocina/ http://www.asiateatro.it/asie/bibliografie/indonesia/ http://www.asiateatro.it/asie/bibliografie/malesia/ http://www.asiateatro.it/asie/bibliografie/tibet/

Nella versione attuale le pagine web sono state accorpate sotto i seguenti URL: http://www.asiateatro.it/giappone/bibliografia-giappone/ http://www.asiateatro.it/india/bibliografia-india/ http://www.asiateatro.it/cina/bibliografia-cina/ http://www.asiateatro.it/asie/bibliografia-asie/

\section{Come citare l'intero fascicolo:}

AsiaTeatro - rivista di studi online, annate 2011-2021, fascicolo 5: Bibliografia dei teatri asiatici.

https://doi.org/10.55154/at.G3564

\section{Come citare questo articolo:}

MARANGONI Rossella (a cura di), "Bibliografia: Altre Asie", AsiaTeatro - rivista di studi online, annate 2011-2021, fascicolo 5: Bibliografia dei teatri asiatici, pp. 57-78 https://doi.org/10.55154/XWRE6050 


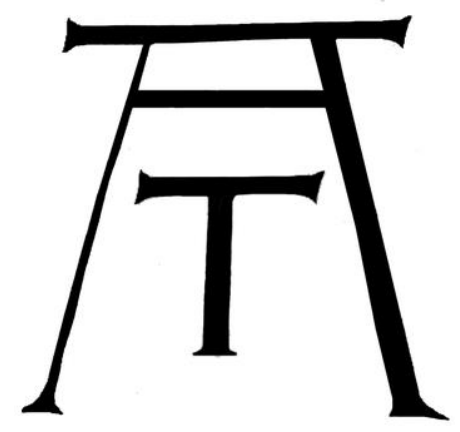

AsiaTeatro - rivista di studi online - ISSN: 2240-4600

annate 2011-2021, fascicolo n.5: Bibliografia dei teatri asiatici

www.asiateatro.it 